\title{
How Does It Fit? Exploring the Congruence Between Organizations and Their Corporate Social Responsibility (CSR) Activities
}

\author{
Menno D. T. de Jong ${ }^{1} \cdot$ Mark van der Meer ${ }^{1}$
}

Received: 12 August 2013/Accepted: 13 July 2015 / Published online: 26 July 2015

(C) The Author(s) 2015. This article is published with open access at Springerlink.com

\begin{abstract}
Several studies have focused on the effects of corporate social responsibility (CSR) fit on external stakeholders' evaluations of CSR activities, attitudes towards companies or brands, and behaviors. The results so far have been contradictory. A possible reason may be that the concept of CSR fit is more complicated than previously assumed. Researchers suggest that there may be different types of CSR fit, but so far no empirical research has focused on a typology of CSR fit. This study fills this gap, describing a qualitative content analysis of the congruence between six organizations and their various CSR activities. Ten annual reports and CSR reports were analyzed, and 102 specific CSR activities were identified. The results show that two levels of fit must be distinguished: based on the means for and the intended ends of the CSR activity. Furthermore, six different types of fit were found, focusing on (1) products and services, (2) production processes, (3) environmental impact, (4) employees, (5) suppliers, and (6) geographical location. Considering the above variety of fit possibilities, the findings emphasize the role of CSR communication as a means of creating fit perceptions.
\end{abstract}

Keywords Corporate responsibility - Corporate social responsibility · CSR · Fit · Congruence · Communication

Menno D. T. de Jong

m.d.t.dejong@utwente.nl

Mark van der Meer

mvandermeer@gmail.com

1 Department of Communication Science - Corporate and Marketing Communication, Faculty of Behavioral, Management, and Social Sciences, University of Twente, P.O. Box 217, 7500 AE Enschede, The Netherlands

\section{Introduction}

In 1917, Henry Ford faced a lawsuit in court, brought by two of his company's shareholders. Ford planned to invest the profit of the organization and suspend most of the dividends (Lewis 1976). He wanted to increase the production of Ford cars and lower their price to enable "a larger number of people to buy and enjoy the use of a car" (p. 100). He envisioned that companies should do "as much as possible for everybody concerned" (p. 100) and that they should try "to make money and use it, give employment, and send out the car where the people can use it... and incidentally to make money" (p. 100). Those thoughts were very innovative for that time, and the shareholders did not agree. They sued Ford, and the judge ordered him to cancel most of the expansion plans and pay the dividends. The general conclusion was that the purpose of a company was not to do as much good as possible, but to make profit.

In the past few decades, however, the idea of organizations making positive contributions to society has gained considerable influence (Lee 2008). Society nowadays expects organizations to be socially engaged. Almost every modern organization is in one way or another involved in corporate social responsibility (CSR) activities. Although there is no universally accepted definition of CSR (Okoye 2009; Van Marrewijk 2003), two features can be used to differentiate CSR activities from other deeds: (1) they (partly or entirely) benefit society and/or general interests, and (2) they are not obligated by law (Arvidsson 2010). In this respect, CSR is a narrower concept than corporate citizenship, which also presumes that an organization fulfills its economic responsibilities and obeys the law (Carroll 1998). CSR activities may be found in various domains, such as environmental friendliness, community 
support, local products promotion, and fair employee treatment (Ailawadi et al. 2014). Many types of stakeholders may be involved: employees, suppliers, customers, communities, the environment, investors, and regulators (Malik 2015).

CSR policies and activities may also take many forms. Three specific forms of CSR that are often studied as separate entities are cause-related marketing (marketing programs that explicitly try to combine sales objectives and helping worthy causes; cf. Varadarajan and Menon 1988), sponsorship (connecting worthy causes explicitly to the name of a brand or organization in exchange for money; cf. Uhrich et al. 2014), and corporate philanthropy (charitable donations, which may or may not lead to tax deductions; cf. Campbell et al. 2002). As these examples show, organizations may also benefit from their CSR activities, and they often do, which may have contributed to the overwhelming attention to the topic of CSR in the recent academic literature.

Organizations may have three basic types of motives for engaging in CSR activities (cf. Groza et al. 2011; Hemingway and Maclagan 2004). The first is intrinsic (also referred to as other-focused, altruistic, values-driven, or public-serving): the organization engages in CSR because it wants to help out and make a societal contribution. Within the intrinsic motives, Graafland and MazereeuwVan der Duijn Schouten (2012) further distinguish between ethical and altruistic motives. Ethical motives refer to a sense of moral duty, while altruistic motives to the desire to help others. The second motive is extrinsic (also referred to as self-focused, strategic, or self-serving): the organization engages in CSR because it expects financial or other benefits from its socially responsible behavior. A great number of studies have focused on the effects of CSR activities on organizational outcomes, many of which (but not all) with positive findings (cf. Graafland and Mazereeuw-Van der Duijn Schouten 2012). Overall, these studies underline the potential of CSR activities for organizational benefits, while the studies without effects call for research into the factors that may have affected such outcomes. The third motive involves meeting societal expectations and stakeholder pressure (also referred to as stakeholder-driven). According to a survey by Morsing and Schultz (2006), organizations are expected to be engaged in CSR: only $4 \%$ of the respondents in their study thought that companies are merely responsible for creating profit for themselves and for their shareholders; $49 \%$ found companies responsible for shareholders, employees, and consumers; another $45 \%$ even thought that companies have a broader social responsibility. Becker-Olsen et al. (2006) found even higher percentages: $80 \%$ of the respondents held the opinion that organizations should engage in social initiatives; $72 \%$ of them thought that organizations could benefit from being engaged. Their study also indicated that
$52 \%$ of the respondents would boycott organizations that are not involved in CSR activities, if competitors are available. A special type of stakeholder pressure involves sustainable supply chain management (cf. Liu et al. 2012). In practice, organizations often have a combination of motives for their CSR activities (Berglind and Nakata 2005). For instance, Garay and Font (2012) found that the main reason organizations have for implementing CSR activities is altruistic, but that competitiveness reasons were also prominent.

Various types of advantages of CSR involvement for the organization itself have been identified in the literature. Research has shown that CSR involvement often leads to competitive advantages, such as a more positive image or reputation, increased purchase intentions among consumers, or consumer loyalty (cf. Aguinis and Glavas 2012a; Du et al. 2010; Smith and Langford 2009; Torres et al. 2012). In addition, CSR may contribute to a substantial reduction of risks and cost of equity (El Ghoul et al. 2011). Several studies suggest that CSR may have a buffering effect in times of product-harm crises (Choi and La 2013; Kim 2014; Klein and Dawar 2004; Lin et al. 2011). Other possible advantages include tax benefits, free publicity, and attractiveness as employer (Kim and Park 2011; Sprinkle and Maines 2010).

CSR may thus be beneficial for society as well as for the organization itself. The benefits for the organization strongly depend on the quality of the CSR communication, which is clearly emerging as a relevant research field within the CSR domain (Arvidsson 2010; Chaudhri 2014; Du et al. 2010; Skard and Thorbjørnsen 2014; Van Rekom et al. 2014). One major problem is that stakeholders are often unaware of the CSR activities of organizations (Beckmann 2007; Du et al. 2010; Fatma and Rahman 2015; Hartmann et al. 2013). A study by Servaes and Tamayo (2013) underlined the importance of public awareness for the outcomes of CSR activities. Experimental studies into the effects of CSR expose participants to CSR information and measure the effects of this exposure, but in real life, consumers may only incidentally expose themselves to such information. A second problem is the risk of skepticism and cynicism among consumers when they are informed about the CSR involvement of organizations (Brønn and Vrioni 2001; Fassin and Buelens 2011; Skarmeas and Leonidou 2013; Skarmeas et al. 2014; Webb and Mohr 1998). Organizations have to operate in an environment in which 'greenwashing' and variations thereof are increasingly prevalent (Chen et al. 2014; Elving and Van Vuuren 2011; Nyilasy et al. 2014), which may at the very least make people vigilant when they are confronted with CSR information. Arvidsson (2010) and Chaudhri (2014) also found that, according to communication professionals, the media often take a negative approach when CSR activities are concerned. The two problems are related: 
raising people's awareness of CSR activities may easily evoke skeptical and cynical reactions. As a result, communicating about CSR activities may be sensitive and complex (Arvidsson 2010; Morsing and Schultz 2006). The basic premise is that organizations must be genuinely concerned with society when participating in CSR activities, instead of appearing to be only in it for making more profit.

One key variable in the communication about CSR may be the fit (or congruence) between an organization and its CSR activities (CSR fit). Du et al. (2010) define CSR fit as "the perceived congruence between a social issue and a company's business" (p. 12). A high CSR fit means that there is a clear relationship between an organization's core business and its CSR activity. McDonald's appeal to its employees to eat less fast food and its initiatives to put more healthy alternatives on the menu are examples of CSR activities with a high fit. A low fit means that the combination of an organization and its CSR activity is more or less random. McDonald's willingness to offer financial support whenever major natural disasters strike could be an example of CSR with a low fit.

Several studies have been conducted into the effects of CSR fit on stakeholders' opinions and attitudes, but the results are not univocal. Most studies confirmed that the CSR fit should be high, suggesting that stakeholders have more appreciation for CSR activities that follow naturally from the organization's core business; some studies yielded results that seem to be in favor of a low or moderate fit; and other studies found no effect at all. Given this discrepancy, it seems worthwhile to take a closer look at the concept of CSR fit. The various studies used experimental approaches, and operationalized CSR fit in specific ways. However, CSR activities may be fruitfully connected to the core of an organization in many ways. CSR activities that are labeled as having a low fit might in fact have a high fit when a more comprehensive perspective on the concept of CSR fit is taken. The possible benefits that are now attributed to a high or a low fit may in fact be the result of more nuanced characteristics of the relationship between an organization and its CSR activities. It may thus be useful for organizations to take a more detailed view on the phenomenon of CSR fit, and use this to optimize the possible benefits of their CSR activities.

Several researchers have proposed typologies of fit, but these typologies are not based on an analysis of existing CSR activities and the organizations behind them. This article tries to fill this gap in the literature. Instead of manipulating CSR fit and investigating the effects, we conducted a qualitative study into the CSR practices of organizations, focusing on the range of possible types of CSR fit. Our research question is: Which types of fit can be distinguished between organizations' core business and their CSR activities?

\section{Conceptual Framework}

Below, we will first discuss the key factors that play a role in achieving positive CSR effects on external stakeholders (mostly consumers). We draw not only on frameworks such as those proposed by Aguinis and Glavas (2012b) and Du et al. (2010), but also on specific empirical studies. Following this, we will discuss the findings regarding the effects of CSR fit on external stakeholders. Finally, we will discuss existing descriptions of types of fit.

\section{Key Factors in Achieving Positive CSR Outcomes}

CSR fit may affect people's attitudes and behaviors toward CSR activities and the organization behind them, but is not likely to do so in a direct way. The fact that CSR activities have a low fit or a high fit does not necessarily imply that they will be judged negatively or positively. The effects of CSR fit are likely to be mediated by variables that involve stakeholders' perceptions of either the CSR activity or the organization. Reviewing the literature on the effects of CSR activities (including corporate philanthropy, sponsoring, and cause-related marketing), two clusters of possibly mediating variables affecting CSR outcomes emerge: stakeholders' appreciation of the cause, and their estimation of the sincerity and credibility of the organization (cf. Barone et al. 2007). The majority of the research so far has focused on sincerity and credibility issues.

Several studies indicate that stakeholders' appreciation of the cause plays an important role in the effects of CSR activities. An important aspect is the extent to which a cause appeals to external stakeholders. Ailawadi et al. (2014), for instance, showed that the effects of CSR activities varied between the four CSR domains they distinguished, and Grau and Folse (2007) found that local donations, as opposed to national ones, had a positive effect on cause-related marketing outcomes. Likewise, Bigné-Alcañiz et al. (2010) found that consumers' social cause involvement moderated the relationship between their consumer-company identification and their behavioral intentions. The costs involved for the stakeholders are another important aspect: Andrews et al. (2014) showed that price discounts moderated the effects of cause-related marketing campaigns, while Folse et al. (2010) found that purchase quantity affected consumers' participation intentions. Andrews et al. (2014) showed that consumers' warm-glow good feelings from cause-marketing campaigns represented the underlying process of cause-related marketing effectiveness. As a result, communication strategies such as positive message framing (Grau and Folse 2007) and vivid cause descriptions (Baghi et al. 2009) appear to be important strategies to improve the outcomes of CSR activities. Brei and Böhm (2014) analyzed how 
organizational discourse functions in creating an appealing cause image and affecting consumers' self-image.

With regard to the sincerity and credibility of the organization, a number of specific clusters of variables have been proposed and investigated. Several studies confirmed the important role sincerity and credibility play regarding the outcomes of CSR activities (Hillenbrand et al. 2013; Hur et al. 2014; Rifon et al. 2004; Walker and Kent 2013). Other studies focused on variables with a clear relation to sincerity and credibility. The first variable involves the perceived CSR motives of the organization (Gao 2009). The bottom line here seems to be that a plausible story about intrinsic (other-focused) motives is a prerequisite (Barone et al. 2000; Folse et al. 2010; Forehand and Grier 2003; Gao and Mattila 2014; Myers et al. 2012; Skarmeas and Leonidou 2013; Skarmeas et al. 2014), but that stakeholders understand and may even appreciate that there are also extrinsic (self-focused) motives involved (Myers et al. 2012; Kim 2014; Kim and Lee 2012; Webb and Mohr 1998). Other studies qualified these findings, suggesting that the differentiation between intrinsic and extrinsic is too coarse-grained (Ellen et al. 2006), which perceived honesty about the motives may be equally important as the motives themselves (Forehand and Grier 2003), and that motives may play different roles for different types of CSR activities (Kim et al. 2012a). A second variable involves the nature of the CSR activities (proactive versus reactive). Groza et al. (2011) showed that proactive CSR activities lead to better consumer responses. A third variable involves the overall positioning of the organization with CSR (Du et al. 2007; Green and Peloza 2014) and CSR reputation (Folse et al. 2010; Servaes and Tamayo 2013; Tao and Ferguson 2015). The last variable is message credibility. Eberle et al. (2013) showed that the credibility of CSR communication positively affects corporate reputation and word-of-mouth (and that interactivity contributes to this credibility). Du and Vieira (2012) showed in a case study how companies use various tactics to "boost the credibility" of their CSR messages (e.g., using factual messages, and two-sided information).

Considering these two possible directions, it seems most plausible that CSR fit affects the perceived sincerity and credibility of the organization (Inoue and Kent 2014). Various studies provide empirical support for this assumption, mostly using mediation analysis (Bigné Alcañiz et al. 2010; Bigné et al. 2012; Bower and Grau 2009; Gorton et al. 2013; Myers et al. 2012; Rifon et al. 2004; Samu and Wymer 2014; Zdravkovic et al. 2010).

\section{Role of CSR Fit}

Although CSR fit may not have direct influence on relevant attitudinal and behavioral CSR outcomes, it may still play an important role in the way external stakeholders make sense of CSR activities. Theoretically, it is grounded in Balance Theory, which assumes that people strive for balance among their attitudes toward related entities (cf. Basil and Herr 2006). However, the available research into the effects of CSR fit did not lead to univocal results. On the one hand, research suggests that a high CSR fit has a positive effect on the CSR outcomes among relevant stakeholders (Becker-Olsen et al. 2006; Becker-Olsen and Hill 2006; Ham and Han 2012; Han et al. 2013; Kim et al. 2012; Koschate-Fischer et al. 2012; Kuo and Rice 2015; Prajecus and Olsen 2004; Samu and Wymer 2009; Simmons and Becker-Olsen 2006). On the other hand, research suggests that CSR fit does not play a significant role (Chernev and Blair 2015; Lafferty 2007, 2009) or that a low or moderate CSR fit may sometimes lead to better CSR outcomes than a high CSR fit (Bloom et al. 2006; Drumwright 1996; Ellen et al. 2000; Kim 2011).

Other studies report conditional effects of CSR fit. Chen et al. (2014) concluded on the basis of an experiment that a high CSR fit is preferable for organizations that are strongly associated with CSR, and a low CSR fit is preferable for organizations that are strongly associated with corporate ability. Menon and Kahn (2003) concluded that a high CSR fit works best for cause promotions, while a low fit is more suitable for advocacy promotions. They also stated that a high fit works best when stakeholders are primarily focused on the sponsor brand, and a low fit is better when they predominantly focus on the social issue. Langen et al. (2013) showed in their study that a high fit is especially important for specific groups of consumers ('lovers' and 'critics'), and not for others ('replacers' and 'label less important'). Likewise, Nan and Heo (2007) showed that a high fit between organizations and their CSR activities is only beneficial in the case of high brand consciousness among consumers.

Explanations for a favorable contribution of a high CSR fit may be found in two directions, both of which seem to focus on the effects of CSR fit on perceived sincerity and credibility. First, several authors argued that a high fit makes the CSR activities more self-explanatory and therefore raises fewer critical questions about the organization's intrinsic motives. Du et al. (2010) stated that a low CSR fit may increase the cognitive elaboration in people, which makes extrinsic motives more salient and weakens the positive reactions toward the organization. In the same vein, Becker-Olsen et al. (2006, p. 47) gave three reasons for the importance of a high fit: it affects (1) how much thought people give to a relationship, (2) which specific types of thoughts are generated, and (3) how the two objects are evaluated. Second, CSR activities with a high fit may be judged more positively for several intrinsic reasons: they may be perceived to be more stable and 
structural, to have a clearer link to the organization as a whole instead of to specific persons within the organization, to be more professional and less amateurish, and to be an indication that social responsibility is an integral part of the organization's business and not a random compensation for business as usual.

An explanation for a favorable contribution of a low or moderate CSR fit would be that stakeholders see a CSR activity as a more deliberate and larger effort when it is further removed from an organization's core business (Drumwright 1996; Ellen et al. 2000). This explanation, in fact, highlights another aspect of perceived sincerity and credibility: the investment of the organization, which has been confirmed as a relevant variable in several studies (Folse et al. 2010; Koschate-Fischer et al. 2012).

Although the results so far are not univocal, the fact that CSR fit may affect external stakeholders' attitudes and behaviors is acknowledged by all researchers. More research is needed into the complex relationship between CSR fit and CSR outcomes. Explanations for differences in the findings have been sought in context and circumstances, for instance consumers' initial trust in the organization's motives (Ellen et al. 2000), the organization's reputation (Elving 2010), or consumers' focus on the message versus the organization (Menon and Kahn 2003). Another explanation may be in the operationalization of fit in the various studies, which appears to differ considerably (cf. Bigné Alcañiz et al. 2010). In the (mainly experimental) studies, CSR fit reflects a local and univocal manipulation in the experimental materials. In daily life, judgments about the fit between an organization and its CSR activities will emerge from the complete information offered by an organization and the sensemaking of that information by the stakeholders. It would therefore be useful to further investigate the possible ways in which CSR fit manifests itself in the CSR communication of organizations. This is the aim of the study described in this article.

\section{Types of Fit}

In general terms, CSR fit refers to the similarity between the characteristics of an organization and the characteristics of its CSR activities (cf. Becker-Olsen et al. 2006; Du et al. 2010). Yuan et al. (2011) labeled this type of fit as "internal consistency," and distinguished two other types of fit that may also be important to consider: "external consistency" (the extent to which the CSR activities meet the demands of external stakeholders) and "coherence" (the compatibility of the various CSR activities of an organization). In our research, we focus on the congruence between CSR activities and the organization's core business.
Various authors have further examined and differentiated the concept of (internal) CSR fit. Yuan et al. (2011) proposed a framework based on the strength of the fit between an organization and its CSR practices, distinguishing between seven patterns, ranging from "born CSR oriented" (when CSR is incorporated as a crucial part of the organization from the beginning) to "cooperating"(when CSR practices are based on alliances). In the same vein, Aguinis and Glavas (2012b) made a more coarse-grained distinction between embedded and peripheral CSR activities. These distinctions reflect intensity and history.

Bigné Alcañiz et al. (2010) and Bigné et al. (2012) distinguished between functional and image fit. Functional fit refers to the type of products (or services) that an organization stands for; image fit refers to a similarity based on brand associations. They show empirically that the two types of fit work differently: functional fit is linked to expertise and has a direct effect on CSR perceptions, while image fit affects CSR perceptions via credibility.

Simmons and Becker-Olsen (2006) distinguished between natural and created fit. Natural fit refers to an obvious relation between organization and cause; created fit is based on systematic communication activities aimed at linking organization and cause. Their research showed that a created fit may mitigate the negative effects of a low fit. Likewise, Woisetschläger and Michaelis (2012) argued against the static CSR fit literature, and conducted a study that showed how a low fit may change over time, through learning and remembering processes, into a high fit.

Kuo and Rice (2015) distinguished between conceptual and perceptual fit. Conceptual fit is based on brand image and positioning, while perceptual fit is based on appearance (e.g., color). Their research showed that perceptual fit may also contribute to the overall fit perception, as well as to the CSR outcomes. Underlying mechanisms for such effects are affective transfer and a fit-as-fluency mechanism.

Menon and Kahn (2003) listed several factors that might contribute to a high CSR fit perception: product dimensions, specific group segments, corporate image associations, and personal involvement. Their distinction, which was not empirically supported, focuses primarily on the content of CSR activities (and as such is most related to the research presented in this article).

Finally, Zdravkovic et al. (2010) presented and investigated several sub dimensions of CSR fit that seem to be a combination of some of the distinctions mentioned above: visibility, explicitness, slogan, mission, and promotional activities refer to created fit; visuals/color to perceptual fit; and target market, geographical compatibility, local attributes, and active involvement to the content of CSR activities. Based on a factor analysis, they concluded that the sub dimensions of fit cluster into two main factors: prominence-based fit, and marketing strategy-based fit. 
Together, these studies suggest that CSR fit may take many forms. In this article, we describe a first attempt to provide a more detailed and systematic view on the various forms of CSR fit, by analyzing the types of CSR fit that occur in practice.

\section{Method}

This study explored the congruence between organizations and their CSR activities. It aimed to compare the characteristics of specific CSR activities with those of the organizations behind them, and by as a result distinguish various forms of CSR fit. To do so, a qualitative content analysis was conducted. A content analysis is a systematic analysis of available information sources, using a sample of messages (the "corpus") and a coding scheme. The coding scheme can be predefined on the basis of the literature, but in the case of more exploratory research questions may also emerge from the data (cf. Potter and Levine-Donnerstein 1999). For an inventory of official CSR initiatives and their relationship to the organizations involved, a content analysis is the most appropriate research method.

\section{Corpus}

Annual year reports and CSR reports are communication means that are generally accepted as proper ways to communicate about the CSR engagement of organizations (Arvidsson 2010). Since organizations normally disclose their CSR activities in these reports and the reports are accessible for everyone, annual year reports and CSR reports are the ideal data source for this study. Therefore, all data for this study were obtained by analyzing the annual reports and CSR reports of Dutch organizations.

To make sure the reports contained valuable information, we only selected organizations that were included in the 2011 edition of the "Transparency Benchmark" of the Dutch government (De Transparantiebenchmark 2012). This benchmark consists of 15 categories and assesses the transparency of organizations concerning their CSR activities. One of the 15 categories, "miscellaneous," was excluded from the research, because it was a repository of very different organizations. From the remaining 14, six categories were randomly chosen. Of each selected category, the most highly ranked organization was included in the research.

Table 1 gives an overview of the organizations included. All organizations had their headquarters in The Netherlands, but worked internationally with locations spread throughout world. All had more than 1000 employees.

All available annual reports and CSR reports of the selected organizations for 2011 were analyzed for CSR activities. In total, ten reports were included in the research: six annual reports and four CSR reports.
Table 1 Organizations included in the research

\begin{tabular}{ll}
\hline Organization & Description \\
\hline 1 & Dairy products \\
2 & Office furniture \\
3 & Consumer goods and healthcare instruments \\
4 & Mail and package delivery \\
5 & Financial services \\
6 & Printing matters \\
\hline
\end{tabular}

\section{Coding Scheme and Analysis}

The analysis consisted of three elements. First, information about the core business of the six organizations was analyzed. Second, the CSR activities of the six organizations were identified and analyzed. Third, the CSR activities were compared with the core business of the organizations involved.

The first step was to build profiles of each participating organization. To ensure the quality and accuracy of the data, the profiles were based on the information provided in the annual reports and the organizations' websites. In a form, the following characteristics were recorded: (1) the founding year, (2) the core business, (3) the number of employees, (4) the location of the headquarters, and (5) the number and nationality of other locations.

The second step involved the identification and analysis of the organizations' CSR activities. The first selection criterion was does society benefit from the activity? Some organizations appeared to describe a broad range of activities as socially responsible. Most of them were included in the dataset, but activities were excluded when it remained unclear how society would benefit from them. In addition, the following criteria were used:

- The activity must be performed voluntarily.

- The activity must not be obligated by law.

- The activity must be concrete (the text made clear what the activity involved).

- The organization itself must participate in the activity.

For each CSR activity, the analysis focused on a precise description of the nature, the means and the ends of the activity, the other parties involved, and the time frame. We marked those CSR activities that could also be labeled as sponsoring or cause-related marketing. In addition, we analyzed whether the document provided a motivation for the CSR activity, and noted whether the CSR activity was regional, national, or international.

The data we used about the CSR activities were entirely based on the annual reports and the CSR reports. As a result, not every question could be answered for every 
activity, which led to differences in the description of specific activities. When no information was provided, the question was skipped.

The third step involved the comparison between the CSR activities and the core business of the six organizations. All possible kinds of similarities between the CSR activities and the organizations involved were written down comprehensively. We then used a Grounded Theory approach (Corbin and Strauss 2008)—with recursive rounds of open coding, sorting, and comparing-until a manageable and exhaustive list of types of CSR fit was established. Grounded Theory is particularly useful in the case of exploratory research, without predefined categories based on previous research.

Two measures were taken to ensure the reliability and validity of our data. First, a second coder was recruited to verify the categorization in a sample of the data. The second coder randomly selected 25 CSR activities from the corpus, and tried to establish their relationship with the organizations' core business. She was not presented with the codes that emerged from the data, but had to formulate the relationship herself. She essentially ended with the same types of CSR fit as those assigned by the first coder. Second, fifteen new CSR activities from other organizations (outside the corpus) were analyzed to make sure that the typology found would also cover new data. All 15 new activities could be easily categorized using the typology developed in the corpus of the six organizations.

\section{Results}

\section{General Description of the Corpus}

From the ten reports, 102 different CSR activities were collected. Table 2 shows the distribution of the activities among the six organizations.

When the corpus is examined in detail, a few things stand out. For only one activity, it was reported that it did not succeed. The organization concerned also explained the reason for the failure and how they replaced the activity

Table 2 Distribution of activities among the six organizations

\begin{tabular}{lc}
\hline Organization & Number of CSR activities \\
\hline 1 & 37 \\
2 & 6 \\
3 & 15 \\
4 & 11 \\
5 & 10 \\
6 & 23 \\
Total & 102 \\
\hline
\end{tabular}

with a different one. A specific set of CSR activities involved partnerships with third parties, which often resulted in a low fit with the organization itself. The time frame of the CSR activities varied strongly; some were one-time-only, others were ongoing. However, some of the one-time-only activities had an ongoing influence. Most of the activities were only held within one country, a few of them (often the larger ones) were international. And although most of the organizations did not explicitly address their own benefits, one of the partners of the selected organizations explicitly stated to have a purely extrinsic motivation, namely to become the trendsetter in their core business.

CSR fit was not explicitly addressed for each CSR activity in the reports, but the reports made clear that the organizations felt the need to reach some degree of congruence between their core business and their CSR activities. The organizations explained their motives for being engaged in their CSR activities in general terms. One of the organizations, for instance, explained its support for various charities by the fact that employees volunteered for the charity organizations involved. Another organization mentioned an ambition to be a key player in its geographical environment as an important reason for its choice of CSR activities. Yet another organization motivated its choice for CSR activities by formulating the desire to counterbalance its possible negative impact on society.

\section{Distinction Between Means-Level and Ends-Level CSR Fit}

A first observation that emerged from the data was that it is important to distinguish between means-level and endlevel CSR fit. In the case of means-level fit, the relationship between the CSR activity and the organization's core business is found in the means the organization uses for the CSR activity. In the case of ends-level fit, the relationship is found in the ends the organization wants to achieve with the activity. This leads to a $2 \times 2$ matrix of CSR fit, in which fit can be determined in two complementary ways (see Table 3). The following examples from the corpus may illustrate the distinction between the two types of fit.

Examples of CSR activities with both means-level and ends-level fit (cell A, $n=69$ ) are (1) the dairy firm's decision to reduce the amount of sugar, fat and salt in products, to enhance consumers' health, and (2) the bank's

Table 3 Means-level and ends-level CSR fit

\begin{tabular}{lll}
\hline & Ends-level fit & No ends-level fit \\
\hline Means-level fit & A $(n=69)$ & B $(n=13)$ \\
No means-level fit & C $(n=13)$ & D $(n=7)$ \\
\hline
\end{tabular}


policy to provide microfinancing to beginning entrepreneurs, to help them get started.

Examples of CSR activities with a means-level fit but without an ends-level fit (cell $\mathrm{B}, n=13$ ) are (1) the printing house's initiative to give underprivileged youngsters the opportunity to make their own magazine, to give them the chance to extend their horizons, and (2) the consumer goods and healthcare instruments firm's policy to encourage and support volunteering work of its employees, to give something back to society.

Examples of CSR activities with an ends-level fit but without a means-level fit (cell $\mathrm{C}, n=13$ ) are (1) the printing house's financial contribution to cultural events in its immediate surroundings, to further the region where it is located, and (2) the bank's initiative to collect and recycle used cell phones of employees, to promote the sustainable use of resources.

Examples of CSR activities with neither means-level nor ends-level fit (cell D, $n=7$ ) are (1) the mail delivery firm's initiative to produce and sell a cookbook, to collect money for children in developing countries for offering meals at school, and (2) the dairy firm's contribution to ergonomic school furniture in a developing country, to enhance the educational situation in this country.

\section{Types of Fit}

In addition to the distinction between means-level and ends-level fit, six intrinsic types of CSR fit emerged from the data. We will discuss them below.

\section{Products and Services}

The first type of CSR fit involves the products or services for which the organization is responsible. In this case, the organization uses its products or services to do well. This type of fit may apply to the means-level and the ends-level. On the means-level, one can think of various product adaptations by the dairy firm, free printing jobs by the printing house, feasible financing offers by the bank, and a reduced sales price of LED lights for a developing country by the consumer goods and healthcare instruments firm. On the ends-level, one can think of objectives that are closely related to the products and services of the organizations, such as consumer health in the case of the dairy firm, and the creation of entrepreneurial opportunities in the case of the bank.

\section{Production Process}

The second type of CSR fit involves the production process. It typically occurs when an organization installs a new machine, uses more sustainable energy sources, or starts using environment-friendly materials. In all cases, it is a form of means-level fit. For instance, the dairy firm replaced a machine with a new one. The old machine discharged salt water into the surface water of the nearby area. The new machine desalinates the water first before discharging it. As a result, the surface water will be less polluted. Another example is that the printing house started using different types of ink and paper, to make the production process more ecological.

\section{Environmental Impact}

A third type of CSR fit relates to an organization's impact on the environment. This type of fit occurs as an ends-level fit. Sustainability, energy saving, reuse, and waste management are keywords here. The office furniture company, for example, developed a policy of maximizing the use of recycled materials and minimizing the use of new and notreusable materials. The mail delivery firm heated the offices with $\mathrm{CO}_{2}$ neutral biogas, and leased cars with a lower $\mathrm{CO}_{2}$ emission. Not all environmentally friendly activities can be framed in terms of a CSR fit. For example, the printing house sponsored a campaign aimed at raising people's awareness of the "plastic soup" in the oceans.

\section{Employees}

The fourth type of CSR fit involves the employees of the organization. In this case, CSR activities are linked to the people working for the organization. This type of fit occurs on the means-level and on the ends-level. In many CSR activities, both the means-level and the ends-level fit are involved. For instance, the consumer goods and healthcare instruments firm had two positive action policies aimed at appointing more women and employees with a different ethnic background in management positions. The bank offered traineeship for people with multicultural backgrounds and created job positions for underprivileged young people. The dairy firm had an active policy of encouraging employees to do sports and eat healthily. Several organizations framed their "new way of working" policy (with flexible work places and the possibility to work from home) as a CSR activity as well. In other cases, there is an end-fit only, in activities supporting charities because employees are volunteering for that specific charity organization. For instance, the printing house supported Cliniclowns, because one of its employees volunteered for them.

\section{Suppliers}

The fifth type of CSR fit involves a look beyond the organization itself; it focuses on the sustainability and social responsibility of the suppliers. The organization is 
actively urging its supplies to also become sustainable or socially responsible. In some cases, the suppliers are encouraged by means of bonuses; in other cases the suppliers are threatened that the business relation may be discontinued. The suppliers-fit can only be found as a means-level fit. The dairy firm, for instance, paid a bonus to farmers who kept their cows outside in the meadows. The consumer goods and healthcare instruments firm explicitly demanded the suppliers to comply with a set of rules and requirements concerning, for example, child labor and the use of hazardous materials. Suppliers were audited on a regular basis, and third parties were given the opportunity to complain about the suppliers.

\section{Geographical Location}

The last type of CSR fit involves the region or the city where the organization is located. This type of fit only occurs as ends-level fit. In particular, one organization in our corpus, the printing house, focused on regional activities. Its engagement exceeded the sponsoring of local initiatives-such as housing for young people with intellectual disabilities, cultural and sports events-but also supported more structural municipal initiatives to enhance the quality of life in the municipality. The printing house clearly saw itself connected to the region and wanted to participate actively.

\section{Distribution of Types of Fit}

To conclude the "Results" section, Table 4 provides an overview of the distribution of the 102 CSR activities over the two levels of fit and the six types of fit. With the exception of geographical location, all types of CSR fit were well-represented in the corpus. Only in 25 of the 102 cases the means-level fit and the ends-level fit corresponded, which underlines the importance of distinguishing between the two levels.

Table 4 Distribution levels and types of fit

\begin{tabular}{lcc}
\hline Type of fit & Means-level fit & Ends-level fit \\
\hline Products and services & 22 & 11 \\
Production process & 26 & 0 \\
Environmental impact & 0 & 44 \\
Employees & 18 & 22 \\
Suppliers & 16 & 0 \\
Geographical position & 0 & 5 \\
No fit & 20 & 20 \\
Total & 102 & 102 \\
\hline
\end{tabular}

\section{Discussion}

\section{Main Findings}

The results of our study show that the concept of CSR fit is more complex and nuanced, and potentially broader than previously suggested. Our analysis of 102 CSR activities of six organizations led to the distinction between meanslevel and end-level CSR fit, and to a categorization of six types of fit. Together, they offer a framework that may be used by practitioners and academics. The framework complements earlier attempts in two ways. First, it has a predominant focus on the possible intrinsic relationships between an organization and its CSR activities. Second, it is based on empirical and systematic research of existing CSR activities.

Our findings connect to some extent to the distinctions proposed by Menon and Kahn (2003) and Zdravkovic et al. (2010). Menon and Kahn (2003) proposed factors that may contribute to a high CSR fit perception, but did not base these factors on systematic empirical research. Two of their factors connect to categories in our framework: product dimensions, and personal involvement. Zdravkovic et al. (2010) found a wide diversity of sub dimensions of fit, but their inventory was part of a more comprehensive study, and the distinction of sub dimensions was based on a limited set of cues (16 cause-related marketing advertisements related to the cause of the Susan G. Komen Breast Cancer Foundation). One of their factors connects to a category in our framework: geographic compatibility.

Furthermore, the framework shows that there may be a lot of space between functional fit and image fit, as previously distinguished by Bigné Alcañiz et al. (2010) and Bigné et al. (2012). Products and services is the category that connects best to the original concept of functional fit. However, the other categories we distinguished do not seem to connect well to the overall description of image fit, with its emphasis on brand associations.

Our framework raises questions about the distinction between natural and created fit (Simmons and BeckerOlsen 2006). The suggestion that this is a clear dichotomy seems to be problematic. Depending on the target audience and the overall positioning of the organization, there may be some degree of naturalness in all fit categories we distinguished, and at the same time all fit categories will require communication to become manifest and effective. The broad range of potential fit categories suggests that every real CSR fit may be natural and created at the same time.

Finally, our findings regarding the CSR activities of the six organizations lead to two conclusions. First, there appears to be a wide diversity of CSR activities and types 
of fit in the daily practice of organizations. Second, CSR fit (broadly defined by our framework) appears to be important for organizations: only in $7 \%$ of the cases, there was no CSR fit at all.

\section{Theoretical Implications}

Our results call for a further reflection on the nature and role of CSR fit. Previous research has treated CSR fit as a manifest phenomenon, which may be strengthened, framed, or primed in CSR communication, which may be univocally operationalized in experimental research, and which can be fruitfully treated as an isolated feature of CSR activities. Considering the broad range of possibilities of establishing a fit between organizations and their CSR activities, it seems more fruitful to acknowledge the communicative nature of CSR fit. Rather than seeing CSR fit as something that is present or absent, we can see CSR fit as something that takes shape in the communicative actions of organizations, and in the subsequent sensemaking processes of relevant stakeholders.

This view connects to the "communication constitutes organizations" (CCO) perspective on corporate and organizational communication (cf. Christensen et al. 2013; Schultz et al. 2013). According to this perspective, CSR and communication about CSR should not be treated as two separate (albeit related) entities, but are inseparably linked. The concept of CSR fit can be seen as a lens through which researchers and practitioners can make sense of the complex of CSR activities and communication in the relationship between an organization and its stakeholders, not as an isolable variable that can be used to make general predictions about the outcomes of the CSR activities of organizations. In that sense, it is not so strange that the research up to now came up with diverging results: CSR fit may be something different across experiments, across CSR activities, across organizations, across stakeholders, and across individuals. The original and straightforward research question whether fit matters may prove to be less important than the more differentiated questions which types of fit matter, why, to whom, and under which circumstances.

\section{Practical Implications}

The implications for practitioners also primarily involve CSR communication. Practitioners may use our framework to critically examine portfolios of an organization's CSR activities and the communication about these activities, to assess potentially new CSR initiatives, and to develop effective communication strategies about an organization's CSR policy and activities. Our research shows that the congruence between an organization and its CSR activities may have many faces and will manifest itself to stakeholders in the communication. To a large extent, CSR fit is a characteristic that can be construed in the CSR communication, and the basic ingredients for this aspect of CSR communication are offered in our framework. As such, our findings draw attention to the role of storytelling in CSR communication. The various possibilities of CSR fit may be one of the central elements for CSR storytelling (Gill 2014; Janssen et al. 2012). The organizations in our sample did not exhaust themselves in explaining the fit of their CSR activities, which may be a missed opportunity in their discourse.

\section{Limitations and Suggestions for Future Research}

It should be noted that our research was limited to organizations' own reports about their CSR activities. We used their own descriptions of CSR activities, and empathically tried to describe the possible fit with the organizations involved. While such an approach proved to be useful to gain insight into the various types of CSR fit, future research should also focus on the organizational and stakeholders' perceptions of CSR fit. It would, for instance, be relevant to see how organizations view the importance of CSR fit, and how they decide to communicate (or not) about it. Or, from a broader perspective, how organizations view their sincerity and credibility with respect to CSR activities, and to what extent CSR fit plays a role in this respect. Likewise, rather than "black box" experiments into the effects of CSR fit, it would be highly relevant to qualitatively examine how (internal and external) stakeholders make sense of the CSR activities of organizations, and how they handle the notion of CSR fit in their deliberations.

A second limitation involves the exhaustiveness of the six categories. We need to stress that we cannot be sure that the six types of CSR fit are exhaustive. As a matter of fact, in the course of writing this article, we found a Dutch organization with an entirely different CSR fit, namely based on its logo. The company has a fire salamander as its logo, and is therefore actively involved in activities to save this species from becoming extinct. Still, it seems plausible that the six types of CSR fit we distinguished will cover the majority of the CSR activities in practice.

\section{Conclusion}

The results of our study showed that the fit between an organization and its CSR activities can take many forms. Research merely focusing on the distinction between high and low fit does not do justice to the complex and diverse ways in which CSR fit is and can be established in practice, and therefore may lead to misleading results. The umbrella 
concept of CSR fit can be more fruitfully explored now we know what exactly may be found under it.

Acknowledgments The authors wish to thank the Section Editor, Adam Lindgreen, and three anonymous reviewers for their insightful, critical, and constructive comments and suggestions, which have strongly contributed to the quality of this article.

Open Access This article is distributed under the terms of the Creative Commons Attribution 4.0 International License (http://crea tivecommons.org/licenses/by/4.0/), which permits unrestricted use, distribution, and reproduction in any medium, provided you give appropriate credit to the original author(s) and the source, provide a link to the Creative Commons license, and indicate if changes were made.

\section{References}

Aguinis, H., \& Glavas, A. (2012a). Embedded versus peripheral corporate social responsibility: Psychological foundations. Industrial and Organizational Psychology, 6(4), 314-332.

Aguinis, H., \& Glavas, A. (2012b). What we know and don't know about corporate social responsibility: A review and research agenda. Journal of Management, 38(4), 932-968.

Ailawadi, K. L., Neslin, S. A., Luan, Y. J., \& Taylor, G. A. (2014). Does retailer CSR enhance behavioral loyalty? A case for benefit segmentation. International Journal of Research in Marketing, 31(2), 156-167.

Andrews, M., Xueming, L., Zheng, F., \& Aspara, J. (2014). Cause marketing effectiveness and the moderating role of price discounts. Journal of Marketing, 78(6), 120-142.

Arvidsson, S. (2010). Communication of corporate social responsibility: A study of the views of management teams in large companies. Journal of Business Ethics, 96, 339-354.

Baghi, I., Rubaltelli, E., \& Tedeschi, M. (2009). A strategy to communicate corporate social responsibility: Cause related marketing and its dark side. Corporate Social Responsibility and Environmental Management, 16(1), 15-26.

Barone, M. J., Miyazaki, A. D., \& Taylor, K. A. (2000). The influence of cause-related marketing on consumer choice: Does one good turn deserve another?. Journal of the Academy of Marketing Science, 28(2), 248-262.

Barone, M. J., Norman, A. T., \& Miyazaki, A. D. (2007). Consumer response to retailer use of cause-related marketing: Is more fit better? Journal of Retailing, 83, 437-445.

Basil, D. Z., \& Herr, P. M. (2006). Attitudinal balance and causerelated marketing: An empirical application of balance theory. Journal of Consumer Psychology, 16(4), 391-403.

Becker-Olsen, K. L., Cudmore, B. A., \& Hill, R. P. (2006). The impact of perceived corporate social responsibility on consumer behavior. Journal of Business Research, 59, 46-53.

Becker-Olsen, K. L., \& Hill, R. P. (2006). The impact of sponsor fit on brand equity: The case of nonprofit service providers. Journal of Service Research, 9(1), 73-83.

Beckmann, S. C. (2007). Consumers and corporate social responsibility: Matching the unmatchable? Australasian Marketing Journal, 15, 27-36.

Berglind, M., \& Nakata, C. (2005). Cause-related marketing: More buck than bang? Business Horizons, 48(5), 443-453.

Bigné Alcañiz, E., Cáceres, R. C., \& Pérez, R. C. (2010). Alliances between brands and social causes: The influence of company credibility on social responsibility image. Journal of Business Ethics, 96(2), 169-186.
Bigné, E., Currás-Pérez, R., \& Aldás-Manzano, J. (2012). Dual nature of cause-brand fit. Influence on corporate social responsibility consumer perception. European Journal of Marketing, 46(3/4), 575-594.

Bigné-Alcañiz, E., Currás-Pérez, R., Ruiz-Mafé, C., \& Sanz-Blas, S. (2010). Consumer behavioural intentions in cause-related marketing. The role of identification and social cause involvement. International Review on Public and Nonprofit Marketing, 7(2), 127-143.

Bloom, P. N., Hoeffler, S., Keller, K. L., \& Basurto Meza, C. E. (2006). How social-cause marketing affects consumer perceptions. MIT Sloan Management Review, 47, 49-55.

Bower, A. B., \& Grau, S. L. (2009). Explicit donations and inferred endorsements: Do corporate social responsibility initiatives suggest a nonprofit organization endorsement? Journal of Advertising, 38(3), 113-126.

Brei, V., \& Böhm, S. (2014). '1L = 10L for Africa': Corporate social responsibility and the transformation of bottled water into a 'consumer activist' commodity. Discourse \& Society, 25(1), 3-31.

Brønn, P. S., \& Vrioni, A. B. (2001). Corporate social responsibility and cause-related marketing: An overview. International Journal of Advertising, 20, 207-222.

Campbell, D., Moore, G., \& Metzger, M. (2002). Corporate philanthropy in the U.K. 1985-2000. Some empirical findings. Journal of Business Ethics, 39(1-2), 29-41.

Carroll, A. B. (1998). The four faces of corporate citizenship. Business and Society Review, 100-101(1), 1-7.

Chaudhri, V. (2014). Corporate social responsibility and the communication imperative: Perspectives from CSR managers. International Journal of Business Communication,. doi:10. 1177/2329488414525469.

Chen, Y.-S., Lin, C.-L., \& Chang, C.-H. (2014a). The influence of greenwash on green word-of-mouth (green WOM): The mediation effects of green perceived quality and green satisfaction. Quality \& Quantity, 48(5), 2411-2425.

Chen, R., Su, S., \& He, F. (2014b). Does cause congruence affect how different corporate associations influence consumer responses to cause-related marketing? Australian Journal of Management, 39(2), 191-206.

Chernev, A., \& Blair, S. (2015). Doing well by doing good: The benevolent halo of corporate social responsibility. Journal of Consumer Research, 41(6), 1412-1425.

Choi, B., \& La, S. (2013). The impact of corporate social responsibility (CSR) and customer trust on the restoration of loyalty after service failure and recovery. Journal of Services Marketing, 27(3), 223-233.

Christensen, L. T., Morsing, M., \& Thyssen, O. (2013). CSR as aspirational talk. Organization, 20(3), 372-393.

Corbin, J., \& Strauss, A. L. (2008). Basics of qualitative research: Grounded Theory procedures and techniques (3rd ed.). Thousand Oaks, CA: Sage.

De Transparantiebenchmark. (2012, November 1). Retrieved from http://www.transparantiebenchmark.nl.

Drumwright, M. E. (1996). Company advertising with a social dimension: The role of noneconomic criteria. Journal of Marketing, 60, 71-87.

Du, S., Bhattacharya, C. B., \& Sen, S. (2007). Reaping relational rewards from corporate social responsibility: The role of competitive positioning. International Journal of Research in Marketing, 24(3), 224-241.

Du, S., Bhattacharya, C. B., \& Sen, S. (2010). Maximizing business returns to corporate social responsibility (CSR): The role of CSR communication. International Journal of Management Review, $12,8-19$. 
Du, S., \& Vieira, E. T., Jr. (2012). Striving for legitimacy through corporate social responsibility: Insights from oil companies. Journal of Business Ethics, 110(4), 413-427.

Eberle, D., Berens, G., \& Li, T. (2013). The impact of interactive corporate social responsibility communication on corporate reputation. Journal of Business Ethics, 118, 731-746.

El Ghoul, S., Guedhami, O., Kwok, C. C. Y., \& Mishra, D. R. (2011). Does corporate social responsibility affect the cost of capital? Journal of Banking \& Finance, 35(9), 2388-2406.

Ellen, P. S., Mohr, L. A., \& Webb, D. J. (2000). Charitable programs and the retailer: Do they mix? Journal of Retailing, 76, 393-406.

Ellen, P. S., Webb, D. J., \& Mohr, L. A. (2006). Building corporate associations: Consumer attributions for corporate socially responsible programs. Journal of the Academy of Marketing Science, 34(2), 147-157.

Elving, W. J. L. (2010). CSR and skepticism: The influence of fit and reputation on skepticism towards CSR communication. Proceedings of the conference on corporate communication (pp. 63-77). New York: Corporate Communication International at Baruch College/CUNY.

Elving, W., \& Van Vuuren, M. (2011). Beyond identity washing: Corporate social responsibility in an age of skepticism. Akademija MM (Slovenian Journal of Marketing), 17, 49-55.

Fassin, Y., \& Buelens, M. (2011). The hypocrisy-sincerity continuum in corporate communication and decision making. Management Decision, 49(4), 586-600.

Fatma, M., \& Rahman, Z. (2015). Consumer perspective on CSR. Literature review and future research agenda. Management Research Review, 38(2), 195-216.

Folse, J. A. G., Niedrich, R. W., \& Grau, S. L. (2010). Cause-relating marketing: The effects of purchase quantity and firm donation amount on consumer inferences and participation intentions. Journal of Retailing, 86(4), 295-309.

Forehand, M. R., \& Grier, S. (2003). When is honesty the best policy? The effect of stated company intent on consumer skepticism. Journal of Consumer Psychology, 13(3), 349.

Gao, Y. (2009). Corporate social responsibility and consumers' response: The missing linkage. Baltic Journal of Management, 4(3), 269-287.

Gao, Y., \& Mattila, A. S. (2014). Improving consumer satisfaction in green hotels: The roles of perceived warmth, perceived competence, and CSR motive. International Journal of Hospitality Management, 42, 20-31.

Garay, L., \& Font, X. (2012). Doing good to do well? Corporate social responsibility reasons, practices and impacts in small and medium accommodation enterprises. International Journal of Hospitality Management, 31(2), 329-337.

Gill, R. (2014). Why the PR strategy of storytelling improves employee engagement and adds value to CSR: An integrated literature review. Public Relations Review,. doi:10.1016/j. pubrev.2014.02.012.

Gorton, M., Angell, R., White, J., \& Tseng, Y.-S. (2013). Understanding consumer responses to retailers' cause related voucher schemes. European Journal of Marketing, 47(11/12), 1931-1953.

Graafland, J., Graafland, J., \& Mazereeuw-Van der Duijn Schouten, C. (2012). Motives for corporate social responsibility. De Economist, 160, 377-396.

Grau, S. L., \& Folse, J. A. G. (2007). Cause-related marketing (CRM): The influence of donation proximity and messageframing on the less-involved consumer. Journal of Advertising, 36(4), 19-33.

Green, T., \& Peloza, J. (2014). How do consumers infer corporate social responsibility? The role of organisation size. Journal of Consumer Behaviour, 13(4), 282-293.
Groza, M. D., Pronschinske, M. R., \& Walker, M. (2011). Perceived organizational motives and consumer responses to proactive and reactive CSR. Journal of Business Ethics, 102, 639-652.

Ham, S., \& Han, H. (2012). Role of perceived fit with hotels' green practices in the formation of customer loyalty: Impact of environmental concerns. Asia Pacific Journal of Tourism Research, 18(7), 731-748.

Han, S., Choi, J., Kim, H., Davis, J. A., \& Lee, K.-Y. (2013). The effectiveness of image congruence and the moderating effects of sponsor motive and cheering event fit in sponsorship. International Journal of Advertising, 32(2), 301-317.

Hartmann, M., Heinen, S., Melis, S., \& Simons, J. (2013). Consumers' awareness of CSR in the German pork industry. British Food Journal, 115(1), 124-141.

Hemingway, C. A., \& Maclagan, P. W. (2004). Managers' personal values as drivers of corporate social responsibility. Journal of Business Ethics, 50, 33-44.

Hillenbrand, C., Money, K., \& Ghobadian, A. (2013). Unpacking the mechanism by which corporate responsibility impacts stakeholder relationships. British Journal of Management, 24(1), $127-146$

Hur, W.-M., Kim, H., \& Woo, J. (2014). How CSR leads to corporate brand equity: Mediating mechanisms of corporate brand credibility and reputation. Journal of Business Ethics, 125(1), 75-86.

Inoue, Y., \& Kent, A. (2014). A conceptual framework for understanding the effects of corporate social marketing on consumer behavior. Journal of Business Ethics, 121(4), 621-633.

Janssen, S., Van Dalfsen, C. K. A., Van Hoof, J. J., \& Van Vuuren, M. (2012). Balancing uniqueness and similarity: A content analysis of textual characteristics in Dutch corporate stories. Public Relations Review, 38, 32-39.

Kim, H.-S. (2011). A reputational approach examining publics' attributions on corporate social responsibility motives. Asian Journal of Communication, 21(1), 84-101.

Kim, S. (2014a). What's worse in times of product-harm crisis? Negative corporate ability or negative CSR reputation? Journal of Business Ethics, 123, 157-170.

Kim, Y. (2014b). Strategic communication of corporate social responsibility (CSR): Effects of stated motives and corporate reputation on stakeholder responses. Public Relations Review, 40, 838-840.

Kim, S.-Y., \& Park, H. (2011). Corporate social responsibility as an organizational attractiveness for prospective public relations practitioners. Journal of Business Ethics, 103, 639-653.

Kim, S., \& Lee, Y.-J. (2012). The complex attribution process of CSR motives. Public Relations Review, 38(1), 168-170.

Kim, E. E. K., Kang, J., \& Mattila, A. S. (2012a). The impact of prevention versus promotion hope on CSR activities. International Journal of Hospitality Management, 31(1), 43-51.

Kim, N., Sung, Y., \& Lee, M. (2012b). Consumer evaluations of social alliances: The effects of perceived fit between companies and non-profit organizations. Journal of Business Ethics, 109(2), 163-174.

Klein, J., \& Dawar, N. (2004). Corporate social responsibility and consumers' attributions and brand evaluations in a product-harm crisis. International Journal of Research in Marketing, 21(3), 203-217.

Koschate-Fischer, N., Stefan, I. V., \& Hoyer, W. D. (2012). Willingness to pay for cause-related marketing: The impact of donation amount and moderating effects. Journal of Marketing Research, 49(6), 910-927.

Kuo, A., \& Rice, D. (2015). The impact of perceptual congruence on the effectiveness of cause-related marketing campaigns. Journal of Consumer Psychology, 25(1), 78-88. 
Lafferty, B. A. (2007). The relevance of fit in a cause-brand alliance when consumers evaluate corporate credibility. Journal of Business Research, 60, 447-453.

Lafferty, B. A. (2009). Selecting the right cause partners for the right reasons: The role of importance and fit in cause-brand alliances. Psychology and Marketing, 26(4), 359-382.

Langen, N., Grebitus, C., \& Hartmann, M. (2013). Success factors of cause-related marketing in Germany. Agribusiness, 29(2), 207-227.

Lee, M.-D. P. (2008). A review of the theories of corporate social responsibility: Its evolutionary path and the road ahead. International Journal of Management Reviews, 10(1), 53-73.

Lewis, D. L. (1976). The public image of Henry Ford: An American folk hero and his company. Detroit, MI: Wayne State University Press.

Lin, C.-P., Chen, S.-C., Chiu, C.-K., \& Lee, W.-Y. (2011). Understanding purchase intention during product-harm crises: Moderating effects of perceived corporate ability and corporate social responsibility. Journal of Business Ethics, 102, 455-471.

Liu, S., Kasturiratne, D., \& Moizer, J. (2012). A hub-and-spoke model for multi-dimensional integration of green marketing and sustainable supply chain management. Industrial Marketing Management, 41(4), 581-588.

Malik, M. (2015). Value-enhancing capabilities of CSR: A brief review of contemporary literature. Journal of Business Ethics, 127(2), 419-438.

Menon, S., \& Kahn, B. E. (2003). Corporate sponsorships of philanthropic activities: When do they impact perception of sponsor brand? Journal of Consumer Psychology, 13, 316-327.

Morsing, M., \& Schultz, M. (2006). Corporate social responsibility communication: Stakeholder information, response and involvement strategies. Business Ethics: A European Review, 15, 323-338.

Myers, B., Kwon, W.-S., \& Forsythe, S. (2012). Creating effective cause-related marketing campaigns: The role of cause-brand fit, campaign news source, and perceived motivations. Clothing and Textiles Research Journal, 30(3), 167-182.

Nan, X., \& Heo, K. (2007). Consumer responses to corporate social responsibility (CSR) initiatives. Journal of Advertising, 36, 63-74.

Nyilasy, G., Gangadharbatla, H., \& Paladino, A. (2014). Perceived greenwashing: The interactive effects of green advertising and corporate environmental performance on consumer reactions. Journal of Business Ethics, 125, 693-707.

Okoye, A. (2009). Theorising corporate social responsibility as an essentially contested concept: Is a definition necessary? Journal of Business Ethics, 89, 613-627.

Potter, W. J., \& Levine-Donnerstein, D. (1999). Rethinking validity and reliability in content analysis. Journal of Applied Communication Research, 27, 258-284.

Prajecus, J. W., \& Olsen, G. D. (2004). The role of brand/cause fit in the effectiveness of cause-related marketing campaigns. Journal of Business Research, 57, 635-640.

Rifon, N. J., Choi, S. M., Trimble, C. S., \& Li, H. (2004). Congruence effects in sponsorship: The mediating role of sponsor credibility and consumer attributions of sponsor motive. Journal of Advertising, 33(1), 29-42.

Samu, S., \& Wymer, W. (2009). The effect of fit and dominance in cause marketing communications. Journal of Business Research, $62,432-440$

Samu, S., \& Wymer, W. (2014). Cause marketing communications: Consumer inference on attitudes towards brands and cause. European Journal of Marketing, 48(7/8), 1333-1353.
Schultz, F., Castelló, I., \& Morsing, M. (2013). The construction of corporate social responsibility in network societies: A communication view. Journal of Business Ethics, 115(4), 681-692.

Servaes, H., \& Tamayo, A. (2013). The impact of corporate social responsibility on firm value: The role of customer awareness. Management Science, 59(5), 1045-1061.

Simmons, C. J., \& Becker-Olsen, K. L. (2006). Achieving marketing objectives through social sponsorships. Journal of Marketing, 70(4), 154-169.

Skard, S., \& Thorbjørnsen, H. (2014). Is publicity always better than advertising? The role of brand reputation in communicating corporate social responsibility. Journal of Business Ethics, 124(1), 149-160.

Skarmeas, D., \& Leonidou, C. N. (2013). When consumers doubt, watch out! The role of CSR skepticism. Journal of Business Research, 66(10), 1831-1838.

Skarmeas, D., Leonidou, C. N., \& Saridakis, C. (2014). Examining the role of CSR skepticism using fuzzy-set qualitative comparative analysis. Journal of Business Research, 67(9), 1796-1805.

Smith, V., \& Langford, P. (2009). Evaluating the impact of corporate social responsibility programs on consumers. Journal of Management \& Organization, 15, 97-109.

Sprinkle, G. B., \& Maines, L. A. (2010). The benefits and costs of corporate social responsibility. Business Horizons, 53(5), 445-453.

Tao, W., \& Ferguson, M. A. (2015). The overarching effects of ethical reputation regardless of CSR cause fit and information source. International Journal of Strategic Communication, 9(1), $23-43$.

Torres, A., Bijmolt, T. H. A., Tribó, J. A., \& Verhoef, P. (2012). Generating global brand equity through corporate social responsibility to key stakeholders. International Journal of Research in Marketing, 29(1), 13-24.

Uhrich, S., Koenigstorfer, J., \& Groeppel-Klein, A. (2014). Leveraging sponsorship with corporate social responsibility. Journal of Business Research, 67(9), 2023-2029.

Van Marrewijk, M. (2003). The impact of CSR on management disciplines. Journal of Business Ethics, 44, 95-105.

Van Rekom, J., Go, F. M., \& Calter, D. M. (2014). Communicating a company's positive impact on society. Can plausible explanations secure authenticity? Journal of Business Research, 67(9), $1831-1838$.

Varadarajan, P. R., \& Menon, A. (1988). Cause-related marketing: A coalignment of marketing strategy and corporate philanthropy. Journal of Marketing, 52(3), 58-74.

Walker, M., \& Kent, A. (2013). The roles of credibility and social consciousness in the corporate philanthropy-consumer behavior relationship. Journal of Business Ethics, 116(2), 341-353.

Webb, D. J., \& Mohr, L. A. (1998). A typology of consumer responses to cause-related marketing: From skeptics to socially concerned. Journal of Public Policy \& Marketing, 17, 226-238.

Woisetschläger, D. M., \& Michaelis, M. (2012). Sponsorship congruence and brand image. European Journal of Marketing, 46(3/4), 509-523.

Yuan, W., Bao, Y., \& Verbeke, A. (2011). Integrating CSR initiatives in business: An organizing framework. Journal of Business Ethics, 101, 75-92.

Zdravkovic, S., Magnusson, P., \& Stanley, S. M. (2010). Dimensions of fit between a brand and a social cause and their influence on attitudes. International Journal of Research in Marketing, 27, 151-160. 